\title{
ULTRAVIOLET DISINFECTION OF POTABLE WATER IN RAINWATER HARVESTING SYSTEMS
}

\author{
Md Kabir Uddin Sikder \\ Corps of Engineers, Bangladesh Army \\ Dhaka, Bangladesh
}

\begin{abstract}
Increasing acceptance of ultraviolet (UV) disinfection in rainwater harvesting systems (RWHS) demands in-depth performance analysis of the disinfection process. UV disinfection is effective against Cryptosporidium, which is resistant to commonly used disinfectants like chlorine and has the ability to inactivate pathogenic microorganisms without forming regulated disinfection byproducts (DBPs). Some recent research works suggest that UV disinfection could be effective for disinfection of water in RWHS. The present study aims to give a brief overview of the components and requirements for rainwater harvesting system designed for potable water use by UV; potential health concerns associated with rainwater; a description of chemical and physical processes that can mitigate theses effects.
\end{abstract}

Keywords- UV Disinfection; Rainwater Harvesting Systems (RWHS); Disinfection Byproducts (DBPs); Potable Water; Potential Health Concerns.

\section{INTRODUCTION}

Use of UV disinfection in RWHS is increasing day by day among the people of all community from the aspects of both public health and water supply. The presence of elevated levels of arsenic in groundwater in many parts of the Bangladesh (BGS and DPHE 2001; Hug et al. 2011; BBS and UNICEF 2015) forced people to choose surface water sources or RWHS for drinking purposes, especially in areas were suitable arsenic-free deep aquifers are not available. Again, scarcity of non-saline and potable ground water aquifers and elevated salinity in surface water in the coastal regions of Bangladesh promoted higher use of surface pond water and RWHS in these regions (Islam et al. 2013). Even in parts of the world where there are abundant sources of surface water, rainwater may provide a relatively safe, pure source of water that is important to the public health (Siegel M. 2015).

The RWHS essentially store the rainwater during the rainy season in household or community level water storage tanks/reservoirs (Islam et at. 2013). Some examples of rainwater harvesting in Bangladesh are enumerated below:
- ABM Water Company, established by young entrepreneur Ataul Karim Selim, has been installed RWHS at MTB Tower situated in Dhaka's Bangla Motor area. In Dhaka region, rainfall averages approximately $1200 \mathrm{~mm}$ per year during rainy season, is suitable for rainwater harvesting. Rainwater is collected from the rooftop and stored in several reservoirs. The plant purifies the water by treating with chemicals. It has the capacity of purifying 10,000 liters of rainwater per hour. This water is purer than the water supplied by WASA (Chandan A.S.K. 2015).

- In the Green City, Iswardi, Pabna, accommodation area for foreigners of Rooppur Nuclear Power Plant (NPP), twenty high-rise buildings have been planned to harvest rainwater as their secondary water source. During rainy season, rainfall averages approximately $800 \mathrm{~mm}$ per year, is suitable for rainwater harvesting.

Rainwater can be used for both non-potable (irrigation, toilet flushing) or for potable uses (drinking, cooking and showering) (Siegel M. 2015). The treatment required for potable uses differs from that required for non-potable use. The purpose of this paper is to describe the design and UV disinfection process of rain harvesting systems for potable water use only. Initially, this paper will give a brief outline of the components and requirements for a rainwater harvesting system by UV disinfection designed for potable water use. Afterward, the potential health concerns associated with rainwater including description of chemical and physical processes that can mitigate theses effects are discussed.

\section{DESIGN OF RAINWATER HARVESTING SYSTEMS}

Rainwater harvesting systems consist of 9 major components: (1) catchment area, (2) gutters, (3) roof wash (first flush/filter) system, (4) pre-storage filter, (5) collection tank, (6) conduits, (7) pump, (8) filtration system, and (9) water treatment system as shown in Figure 1 below: 


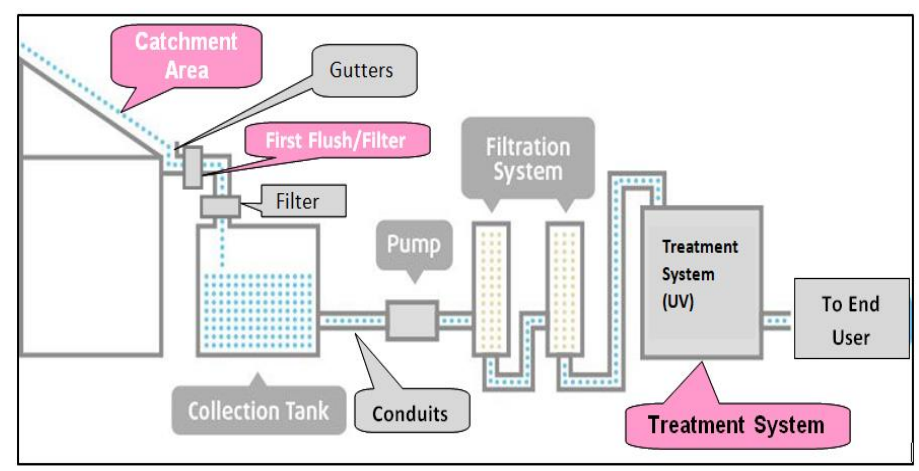

Figure 1: Components of Rainwater Harvesting System

- Catchment Area. Rainwater catchment area can include both rooftops and ground surfaces; only roof-based collection systems will be discussed in this paper. The first thing to consider is whether enough rainfall can be collected to provide sufficient water for the intended use. This depends on the size of the catchment area, rate of rainfall, collection efficiency, and the water demand. Both the average annual rate of precipitation and the length of dry seasons must be considered in system design. An average annual rainfall of at least $60 \mathrm{~mm}$ is generally required if rainwater is to be the sole water source.

- Yearly Water Demand: In urban areas of Bangladesh, ranges of water demand vary from 215 to 270 liters/person/day; a suitable rule thumb is to assume 270 liters of water per day per person. So for a 5 person household, the annual water demand is:

270 liters/day-person $\mathrm{x} 365$ days $\times 5$ persons $=$ 492750 liters

The actual demand will depend on a number of life style choices such as: use of showers or baths, washing clothes at home or at a Laundromat, gardening and outside irrigation. Use of other sources of water such as: ponds, tube well, canals and rivers will also reduce the water demand from rainwater harvesting.

- Quantity of rain that can be harvested: The amount of water that can be harvested by a roof depends on the horizontal projection of the roof surface and the amount that is lost by vaporization, diversion by the roof washer, and leakage. The actual amount harvested will depend on how well the system is maintained (leakage of gutters, and other parts of the water conveyance system) and existence of overheard obstacles (tree branches etc.). The amount of water that can be harvested and stored must be large enough to supply water during period of dry season. The required storage is simply the product of daily use (liters/day) and number of continuous drought days. This amount must be considered in designing the storage tank.
- Gutters. Gutters are the channels all around the edge of a sloping roof to collect and transport rainwater to the collection tank as shown in Figure 2. Gutters can be semicircular or rectangular.

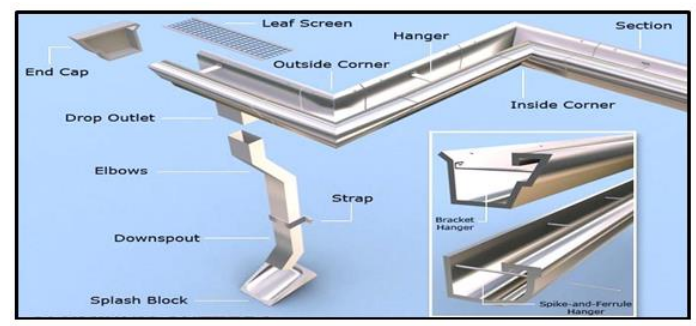

Figure 2: Typical Gutter used in RWHS

- Roof Wash Systems or First Flush/Filter Systems. This is a system for keeping dust and other pollutants (bird droppings, leaves) that have settled on the roof from reaching the storage tank as shown in Figure 3. It is not required for systems designed for non-potable water use, but it is required for potable use systems. It is designed to expulsion the initial water flowing off the roof during the rainfall.

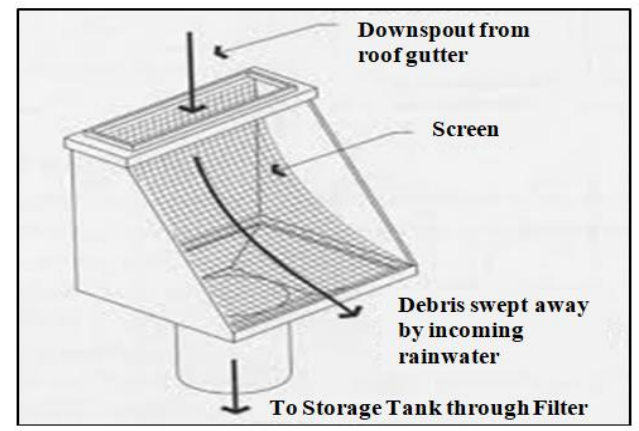

Figure 3: Typical First Flush Filter

- Pre-storage Filter. This part of the system keeps large particulates and debris from entering the storage tank even after the roof wash system has done its job. It may consist of a domed stainless steel screen placed over the inlets leading to the storage tank. They may include leaf guards where windblown debris or overhanging trees are significant.

- Collection/StorageTank. This may be the most expensive part of the system. Collection/Storage Tank are used for untreated water storage and are sized to hold enough water to supply water through the drought days. They are made of a variety of materials including ferro-cement, concrete, galvanized steel, fiberglass and polyethylene. They can be located above ground, in basement or enclosure or buried below ground depending on site-specific conditions. Typical sizes range from less than 25000 to 50000 liters. 


\section{International Journal of Engineering Applied Sciences and Technology, 2020 \\ Vol. 4, Issue 11, ISSN No. 2455-2143, Pages 557-563 \\ Published Online March 2020 in IJEAST (http://www.ijeast.com)}

- Conduits. Conduits are pipelines or drains that carry rainwater from the catchment or rooftop area to the harvesting system. Conduits can be of any material like polyvinyl chloride (PVC) or galvanized iron (GI), materials that are commonly available. The following table (Table 1) gives an idea about the diameter of pipe required for draining out rainwater based on rainfall intensity and roof area:

Table 1: Sizing of rainwater pipe for roof drainage

\begin{tabular}{|c|c|c|c|c|c|c|}
\hline $\begin{array}{c}\text { Diameter } \\
\text { of pipe } \\
(\mathrm{mm})\end{array}$ & \multicolumn{7}{|c|}{ Average rate of rainfall in mm/h } \\
\hline & $\mathbf{5 0}$ & $\mathbf{7 5}$ & $\mathbf{1 0 0}$ & $\mathbf{1 2 5}$ & $\mathbf{1 5 0}$ & $\mathbf{2 0 0}$ \\
\hline 50 & 13.4 & 8.9 & 6.6 & 5.3 & 4.4 & 3.3 \\
\hline 65 & 24.1 & 16.0 & 12.0 & 9.6 & 8.0 & 6.0 \\
\hline 75 & 40.8 & 27.0 & 20.4 & 16.3 & 13.6 & 10.2 \\
\hline 100 & 85.4 & 57.0 & 42.7 & 34.2 & 28.5 & 21.3 \\
\hline 125 & - & - & 80.5 & 64.3 & 53.5 & 40.0 \\
\hline 150 & - & - & - & - & 83.6 & 62.7 \\
\hline
\end{tabular}

Source: Bangladesh National Building Code (BNBC)

- Pump. A pump is used to delivery water from the storage tank to the treatment system through filtration system unless gravity-flow is possible. The pumps, conduits and orifices must be sized to allow delivery to other tanks used for treated water storage and pressurized water storage depending on the system design and intended use of water.

- Filtration System. The filter is used to remove suspended particles from rainwater collected over roof before entering the treatment/disinfection system. A filter unit consists of two layers of sediment filters of $100 \mathrm{UM}$ and 5 UM sizes respectively as shown in Figure 4 below.

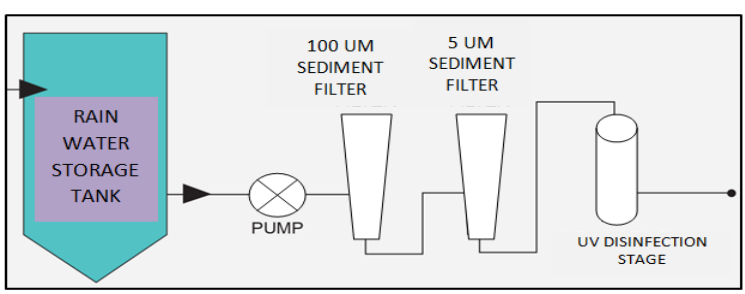

Figure 4: Rainwater Harvesting Filtration System

- Water Treatment/Disinfection System. This may take place at the point-of-entry into the house, at point-of-use taps or combination of both. The system consists of several components and likely to be the most complicated part of the system. The design will depend on various factors related to intended use (potable or non-potable), water demand, and relationship of the harvested water system to supplementary sources of water. Processes include: filtration and disinfection as discussed in more detail later.
Various disinfection methods include: Chlorination, Ozonation, Boiling, nanofiltration, reverse osmosis (RO), $\mathrm{UV}$ radiation, and a combination of UV and Ozonation. But due to increasing acceptance of UV disinfection for small water supply systems (e.g. RWHS, household-level water supply), UV disinfection will be used for water treatment. Treatment goals for potable water is shown in Table 2 below:

Table 2: Treatment Goals for Potable Water in RWHS

\begin{tabular}{|c|l|}
\hline Subject & \multicolumn{1}{|c|}{ Potable System } \\
\hline Treatment Goals & Total Coliform: 0 \\
& Fecal Coliform: 0 \\
& Protozoan Cysts: 0 \\
& Viruses: 0 \\
& Turbidity: < 1 NTU \\
& Water should be tested monthly. \\
\hline
\end{tabular}

\section{CONTAMINANTS POTENTIALLY PRESENT IN HARVESTED RAINWATER}

Microbial contamination comes from fecal contamination from birds and small mammals, leaf litter, mosquitoes, other insects and lizard accumulations as shown in Table 3. They pose a greater threat than the chemical contaminants because (a) they can cause disease after a single exposure, (b) pathogen levels can rise very quickly and (c) diseases can be spread from person to person. Waterborne illnesses can be a serious threat to the elderly, infants, chemotherapy patients and other people with delicate or weakened immune systems.

Table 3: Types and Sources of Pathogens that can be Found in Harvested Rainwater

\begin{tabular}{|c|l|l|}
\hline Type of Pathogen & \multicolumn{1}{|c|}{ Organism } & \multicolumn{1}{|c|}{ Source } \\
\hline \multirow{5}{*}{ Parasite } & Giardia lamblia & $\begin{array}{l}\text { cats and wild } \\
\text { animals }\end{array}$ \\
\cline { 2 - 3 } & $\begin{array}{l}\text { Cryptosporidium } \\
\text { parvum }\end{array}$ & $\begin{array}{l}\text { cats, birds, } \\
\text { rodents, and } \\
\text { reptile }\end{array}$ \\
\cline { 2 - 3 } & $\begin{array}{l}\text { Toxoplasma } \\
\text { gondii }\end{array}$ & $\begin{array}{l}\text { cats, birds, and } \\
\text { rodents }\end{array}$ \\
\hline \multirow{5}{*}{ Bacteria } & $\begin{array}{l}\text { Campylobacter } \\
\text { parvum }\end{array}$ & birds and rats \\
\cline { 2 - 3 } & $\begin{array}{l}\text { Salmonella spp. } \\
\text { cats, birds, } \\
\text { rodents, and } \\
\text { reptile }\end{array}$ \\
\cline { 2 - 3 } & Leptospira spp. & mammals and \\
\cline { 2 - 3 } & Escherichia coli & $\begin{array}{l}\text { birds } \\
\text { mammals }\end{array}$ \\
\hline Virus & Hantavirus spp. & rodents \\
\hline
\end{tabular}

Source: Siegel M. (2015) 


\section{International Journal of Engineering Applied Sciences and Technology, 2020 Vol. 4, Issue 11, ISSN No. 2455-2143, Pages 557-563 \\ Published Online March 2020 in IJEAST (http://www.ijeast.com)}

\section{REMOVAL PROCESSES OF ROOF TOP CONTAMINANT}

Both physical and chemical methods can remove contaminants from the roof top. Wind scour can be effective in removing contaminants. Roof surfaces sloping away from industry often have lower concentrations of industrial pollutants than those that face towards sources of pollution because they are exposed to cleaner winds. In heavily industrial areas, therefore, some roof surfaces may be better for rainwater harvesting than others depending on the direction of prevailing winds.

Roof wash systems take advantage of the initial period of a rain event in which much of the rooftop contamination is entrained by water flowing on the roof. A properly designed rainwater systems for potable water will include a first-flush filter (see Figure 3 above). The amount of water required to rinse the roof depends on: (a) the amount and type of rooftop contamination (dust and debris are easier to remove than fecal matter) (b) the slope of the roof (steeper slopes rinse more rapidly), (c) the porosity of the roof (nonporous materials clean more rapidly), and (d) the rainfall rate (long slow drizzles are less effective than a brief heavy rainfall). It is to be noted here that the amount of turbulent mixing and resulting entrainment of debris and contaminants in the diverted volume that can flow into the storage tank was not discussed in any of the references that I consulted.

\section{PURIFICATION OF POTABLE WATER}

The primary barrier to bacterial contamination in potable water systems is the purification system, which will consist of mainly two steps: filtration and disinfection. Figure 4 illustrates the relations of these components for a system that does not have a treated water storage tank. Filtration is done by using $100 \mathrm{UM}$ and $5 \mathrm{UM}$ sediment filters to remove large parasites and few viruses. As filters do not remove bacteria and all viruses so disinfectant is required. Due to increasing acceptance of UV disinfection for small water supply systems (e.g. RWHS, household-level water supply), UV disinfection is used for water treatment as discussed in next paragraph.

\section{UV DISINFECTION PROCESSES IN RWHS}

Interests in UV radiation are increasing as an alternative to chemical treatments largely as a result of concern over toxic chemical byproducts. Again UV light has proven effective against Cryptosporidium, which is resistant to commonly used disinfectants like chlorine. UV treatment is unique in its mode of action in that it does not necessarily kill the target organism, instead the radiation alters cell DNA so that the organism is sterilized (Smith G. 2011). This serves to inactivate the pathogen so that it cannot proliferate and cause disease. But organisms can sometimes repair and reverse the destructive effects of UV through a "repair mechanism", known as photoreactivation, or in the absence of light known as dark repair. The ability to reactivate varies significantly depending on the type of UV damage inflicted and by the level of biological organization of the microorganism. The repair mechanism is not universal and there are no clearly defined characteristics determining which species can repair themselves and those which cannot (Dulbecco R. 1950).

A water tank needs to be placed at household level where water will deposit for drinking, after filtration, from RWHS. To disinfect by UV, an arrangement was made for fitting UV lamp at the top-center of the container as shown in Figure 5. An UV lamp set is composed of a lamp envelop (quartz glass), an adapter to connect to power supply, and UV lamp itself. At first UV lamp was connected with the adapter then the lamp was placed inside the lamp envelop. Open end of the lamp envelop was made water tight so that water cannot come in contact with UV lamp. An opening was made on the topcenter of the container to fix the UV lamp. Finally, this opening was also made air tight so that UV light did not come in contact with eyes.

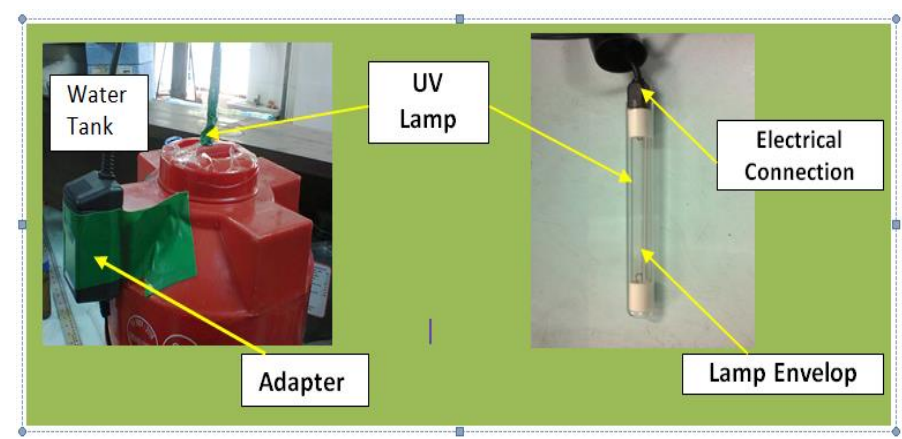

Figure 5: Arrangement for fitting UV lamp at the top-center of the water tank

\section{EFFECTIVENESS OF UV DISINFECTION}

The important factors affecting the effectiveness of UV disinfection include: (1) UV lamp intensity, (2) UV lamp exposure time, (3) distance of collection point/sampling port from UV lamp, (4) distance from UV Lamp, (5) initial FC concentration, (6) turbidity, (7) color, and (8) $\mathrm{pH}$ value. The effects of these factors on the effectiveness of UV disinfection were finding out based on laboratory experiments. These experiments were conducted on two different sizes of water tank (15 and 60 Liter) with two UV lamps of varying intensity. Water collection points of both the water tanks are shown in Figure 6 and 7 below: 

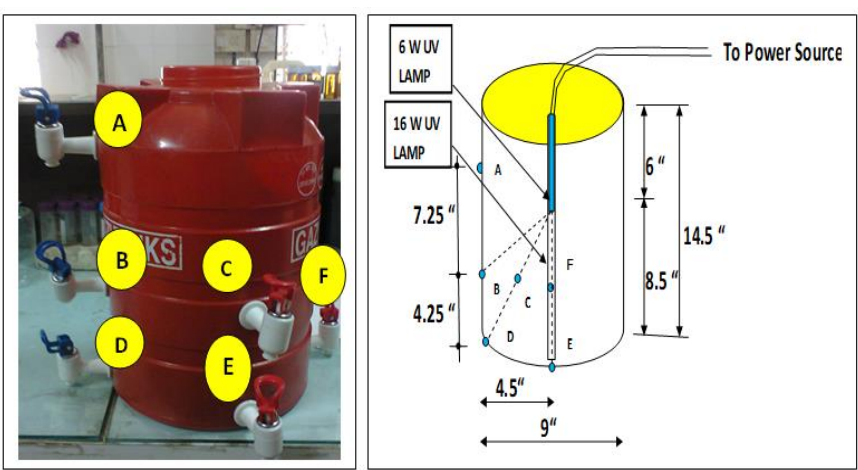

Figure 6: 15 Liter Water Tank with Sample Collection Port
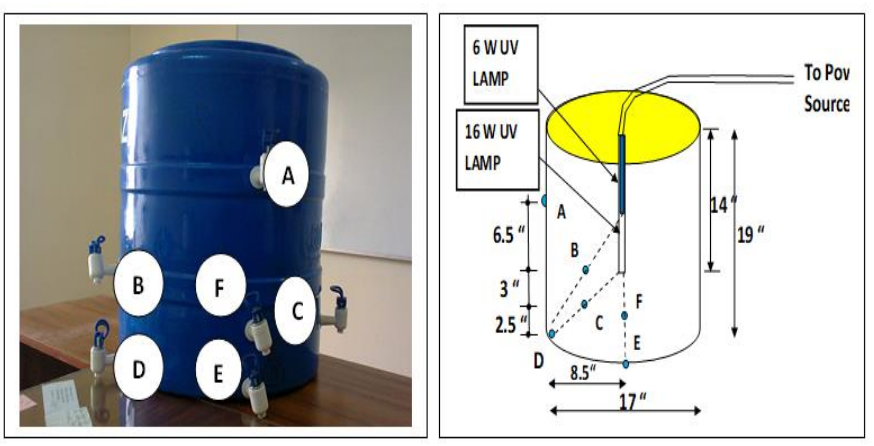

Figure 7: 60 Liter Water Tank with Sample Collection Port

For better comprehension, the results of the laboratory experiments could be summarized as follows:

Table 4: Table Showing Effect of Different Operational and Water Quality Parameters on UV Disinfection

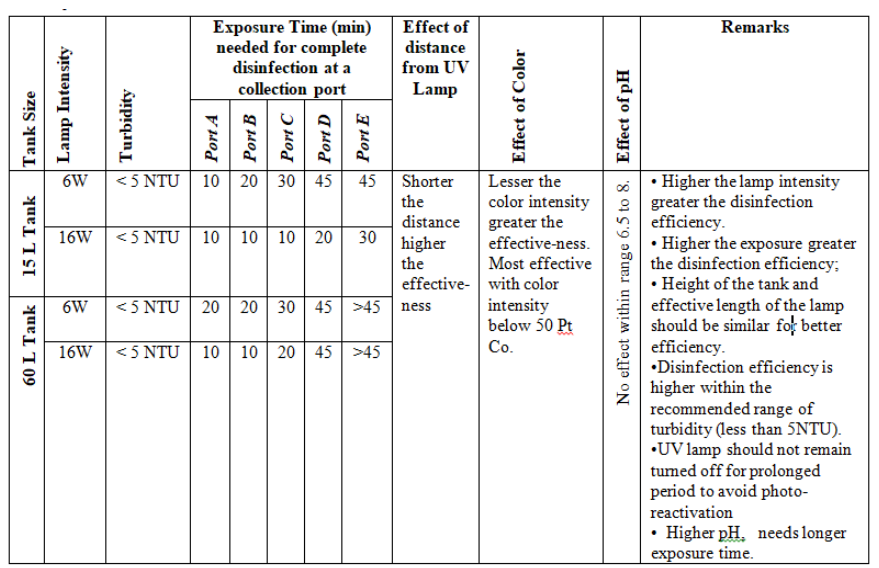

\section{DESIGN OF UV WATER TREATMENT TANK}

Basing on the results of the effectiveness of UV disinfection, UV water treatment tank for RWHS should be designed as follows:

- Selection of Water Tank and Position of UV Lamp on the Water Tank: Water tank should preferably be cylindrical and position of UV lamp in the water tank should be at the center. Height of water tank should approximately be the same as effective length of the UV lamp; in other words, for optimum results, UV lamp should cover the entire height of the disinfection tank, as shown in Figure 8.

- Selection of UV Lamp: Selection of UV lamp should be such that its length commensurate with the height of the water tank.

- Collection Port: Collection port should be located at a position perpendicular to the UV lamp, as shown in Figure 8.

- Quality of water to be disinfected: Turbidity of water to be disinfected should be below 5 NTU, color intensity should be below $50 \mathrm{Pt} \mathrm{Co}$ and lower initial FC concentrations are preferable.

- Exposure Time: If the above criteria could be fulfilled, an exposure time of about 30 minutes should be enough for effective disinfection (i.e. reducing FC to zero level in the treated water).

- Consumption Period: Disinfected water should be consumed within 6 to $8 \mathrm{hr}$ to avoid the photo reactivation or dark repair.

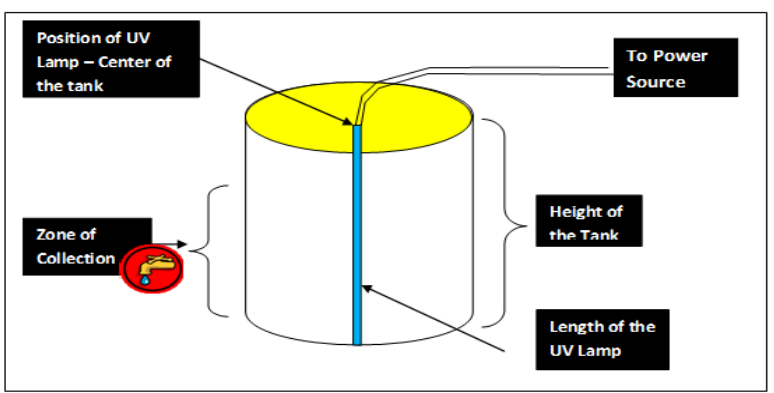

Figure 8: Typical Water Tank for UV Disinfection

\section{BENEFITS AND RISKS FROM USE OF HARVESTED RAINWATER}

There is some evidence suggesting that it may be safer to drink properly harvested rainwater than water from public water systems (PWS). An epidemiological study of 1000 participants showed that those drinking chlorinated filtered 


\section{International Journal of Engineering Applied Sciences and Technology, 2020 \\ Vol. 4, Issue 11, ISSN No. 2455-2143, Pages 557-563 \\ Published Online March 2020 in IJEAST (http://www.ijeast.com)}

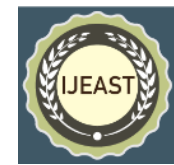

water from a PWS reported higher rates of gastrointestinal sickness than those drinking rain harvested water (TCEQ, 2007).

The Natural Organic Matter or Total Organic Content of rainwater is very low; therefore, the risk of DBP formation is lower in rainwater than in ground or surface waters. Again, $\mathrm{UV}$ as a disinfectant is often preferable due to its ability to inactivate pathogenic microorganisms without forming harmful DBPs. Besides, UV light has been proven effective against Cryptosporidium, which is resistant to commonly used disinfectants like chlorine. The purity of properly harvested rainwater, however, carries its own health risks. The absence of essential nutrients in rainwater has health implications: lack of calcium and magnesium increases the risk of cardiovascular diseases; the lack of fluoride increases the risk for dental caries (Siegel Malcolm 2015). Care must be taken to include vitamin supplements in the diet if harvested rainwater is the sole source of drinking water.

\section{CONCLUSIONS}

From the facts from the study above it is evident that UV disinfection system is most effective in RWHS for potable water. UV disinfection is preferable due to its ability to inactivate pathogenic microorganisms without forming harmful DBPs. Besides, UV light has been proven effective against Cryptosporidium, which is resistant to commonly used disinfectants like chlorine. The effectiveness of UV disinfection depends on a number of operational and water quality parameters including lamp intensity, exposure time, distance of collection point/sampling port from UV lamp, initial FC concentration, turbidity, color, and $\mathrm{pH}$ value. Turbidity of water to be disinfected should be below 5 NTU, and color intensity should be below $50 \mathrm{Pt} \mathrm{Co.} \mathrm{While} \mathrm{lower}$ initial FC concentrations are preferable, if other conditions/criteria (discussed below) could be fulfilled, initial FC concentration is probably not a major concern. No effect was observed within $\mathrm{pH}$ range 6.5 to 8 but for higher $\mathrm{pH}$, needs longer exposure time. Water tank should preferably be cylindrical and position of UV lamp in the water tank should be at the center. Height of water tank should approximately be the same as effective length of the UV lamp. The UV lamp should be selected such that the entire height of water column within the tank is covered by the lamp. Treated water collection port should be located at a position perpendicular to the UV lamp, few centimeters above the bottom of the tank. If the above criteria could be fulfilled, an exposure time of about 30 minutes should be enough for effective disinfection of a particular volume of water (i.e. reducing FC to zero level in the treated water). UV lamp should not remain turned off for prolonged period to avoid photo-reactivation. Disinfected water should be consumed within 6 to 8 hour to avoid the photo reactivation or dark repair.
The absence of essential nutrients in rainwater has health implications: lack of calcium and magnesium increases the risk of cardiovascular diseases; the lack of fluoride increases the risk for dental caries. Care must be taken to include vitamin supplements in the diet if harvested rainwater is the only source of drinking water.

\section{ACKNOWLEDGEMENT}

The author gratefully acknowledges his profound gratitude to his supervisor Dr. M. Ashraf Ali, Professor, Department of Civil Engineering, Bangladesh University of Engineering and Technology (BUET) for his constant supervision, jovial support, continuous guidance and encouragement at every stage of the work. The author is grateful to Dr. Mahbuboor Rahman Chowdhury, Assistant Professor, Department of Civil Engineering, BUET for their encouragement, valuable comments, and suggestions regarding the study. The author is thankful to Mr. Ehsan, Senior Laboratory Instructor of Environmental Engineering Laboratory, Mr. Enamul, Mr. Mithu, Mr Abbas and Mr. Shajalal of the same laboratory for their help and cooperation.

Finally, the author expresses his thanks to his wife, daughter and son for their sacrifice, continuous encouragement and support.

\section{REFERENCES}

[1] BBS and UNICEF (2015). Multiple Indication Cluster Survey, 2012-2013, Progotic Pathey, Final Report, Bangladesh Bureau of Statistics (BBS), Dhaka, Bangladesh and United Nations Children's Fund (UNICEF), Dhaka, Bangladesh. http://www.unicef.orgfoangladesh/MICS_Final_ 21062015_Low. pdf (accessed 20 October 2019).

[2] BGS and DPHE (2001). Arsenic Contamination of Groundwater in Bangladesh", Report WC/00/19. British Geological Survey (BGS), Keyworth and Department of Public Health Engineering (DPHE), Bangladesh. http://www.bgs.ac.uk/research/groundwater/health/arsenic/Ban gladesh/reports.html (accessed 20 October 2019).

[3] Hug S.J., Gaertner D., Roberts L.C., Schirmer M., Ruettimam T., Rosenberg T.M., Badruzzaman A.B.M. and Ali M.A. (2011). Avoiding high concentrations of arsenic, manganese and salinity in deep tubewells in Munshiganj District, Bangladesh. Applied Geochemistry, 26(7), (pp.10771085).

[4] Islam M.A., Sakakibara H., Karim M.R. and Sekine M. (2013). Potable water scarcity: options and issues in the coastal areas of Bangladesh. Water Journal of Bangladesh, 11(3), (pp. 532-542). 
[5] Siegel M. (2015). Water Treatment in Rainwater Harvesting Systems for Potable Use. Water Resources Action Project, Inc. 2015 (pp. 1-16)

[6] Dulbecco, R. (1950), "Experiments on photo reactivation of bacteriophages inactivated with Ultraviolet radiation". Journal of Bacteriology, 59, (pp. 329-347).

[7] TCEQ, 2007. Harvesting Storing, and Treating Rainwater for Domestic Indoor Use, Texas Commission on Environmental Quality, Austin, TX.

[8] Rupp, G. (1998). Rainwater Harvesting Systems for Montana, MT907, MSU Extension Service, Montana State University.

[9] Smith, G. (2011), "UV DISINFECTION \& VALIDATION".http://www.fluidquip.com.au/imagesDB/new s/UVinWaterTreatment.pdf.

[10] Chandan A.S.K. (2015), "A Solution to Water Crisis", The Daily Star, Star Weekend, Spotlight, 20 March 2015. https://www.thedailystar.net/star-weekend/spotlight/ solution-water-crisis-72324.

[11] BNBC (1993/2006). Part 8, (Pg.45) http://bnbcinfo. blogspot.com/p/bnbc-1993.html.

[12] Gates, F.L. (1929). A study of the bactericidal action of ultraviolet light". Journal of General Physiology 13. (pp. 231-260). 